\title{
THE UNDERSTANDING OF INTERNATIONAL TOURISM DEVELOPMENT
}

\author{
Marcus van der Wal
}

\author{
General Manager and Area Director Central Europe Kempinski Hotels
}

\begin{abstract}
Tourism is travel for recreational, leisure or business purposes. Tourism has become one of the major players in international commerce, and represents at the same time one of the main income sources for many developing countries. This growth goes hand in hand with an increasing diversification and competition among destinations (Unwto, 2010). Working and serving in this pumping industry means to understand and react to the needs of all these people moving around this "small" planet! Success is defined by those who understand these needs and fulfill them to the satisfaction. Unfortunately, our industry is rather slow and we can be characterized as reactive instead of innovative. We adapt too slow compared to other industries that define the needs of their costumers before the costumers actually calls for it!
\end{abstract}

Key words: tourism, motivation, market development, touristic services, destinations

Since there is Mankind there has been "tourism". Maybe we have called it with different words to explain e.g.: hunting, discovering, invading, immigrating, etc. But at the end of the day, moving from one place to the other is "traveling" and overall that is "tourism".

The fact is that on and around our planet the speed and ways to travel is developing and with it all the technology involved. With this development the cost of traveling is decreasing and ever more people have the financial means to do so. Our world is becoming smaller and smaller in sense of moving around. People are curious and continuously want to discover other places for business or vacation. Discover new destinations!

Tourism is travel for recreational, leisure or business purposes. The World Tourism Organization defines tourists as people who travel to and stay in places outside their usual environment for more than twenty-four (24) hours and not more than one consecutive year for leisure, business and other purposes not related to the exercise of an activity, remunerated from within the place visited. Today, the business volume of tourism equals or even surpasses that of oil exports, ýfood products or automobiles. Tourism has become one of the major players in ýinternational commerce, and represents at the same time one of the main income ýsources for many developing countries. This growth goes hand in hand with an ýincreasing diversification and competition among destinations (Unwto, 2010).

Working and serving in this pumping industry means to understand and react to the needs of all these people moving around this "small" planet! Success is defined by those who understand these needs and fulfill them to the satisfaction.

Unfortunately, our industry is rather slow and we can be characterized as reactive instead of innovative. We adapt too slow compared to other industries that define the needs of their costumers before the costumers actually calls for it! A good example is the automotive industry that invests high amounts of money in developments of new models. By this, they create the need of the costumer and educate what the clients would like to have in the future. They kick off the desire to have these new cars and make the costumer dream! Obviously the industry understands and takes other external factors in to account, e.g. the lack of raw oil in the world.

In our popular industry we have still failed to notice the two largest potential markets that are up coming. China and India with their huge population will develop and dominate the future tourism movements soon. The tourism market in India shows an enormous development according to statistical analysis (Chaitip et al., 2010). Actually, I strongly believe that they will surpass the US and Europe fairly soon, just out of the fact that the population numbers are as big as they are. Again, we are reactive and observe that there will be born a need to satisfy these emerging markets. Again, I have not seen strong developments to prepare for these very large tourism movements.

Coming to Hungary one has to admit that we are not doing enough to make our very attractive destination known. My criticism has always been, that we are simply not understanding how people are not aware of us here in the heart of Europe! Lack of investment from the side of the Government is one of the reasons for this tragedy! But, where there is not enough money from the tax payers, there can not be money to strongly invest in the attractiveness of the country. This is sad and unfortunately, I don't see a fast improvement in the coming years! Our neighbors have done their homework better. Croatia for example as past us with very high speed and we stand next to the highway and have 
no idea why. During these two days of this conference you can listen to valuable presentations on the emerging trends of medical tourism in Hungary from the aspects of potential Western-European patients (Simor, 2010) and of the service providers and Hungarian subregions - destinations (Kormosné Koch, 2010). Another important topics also will be discussed such as the touristic programs - product development, considering the local traditions, e.g. gastronomy (Tóth-Török, 2010) and the rural toursim as a whole (Tikász et al., 2010). Considering the modern tourism section the importance of environmental awareness (Kelemen et al., 2010), the connection of IT and tourism (e.g. Hering, 2010) will also be in the pot.

At the end of these two days our business is simple! We have to develop guest satisfaction; we need qualified new products and services, all that we call a good destination! Understanding your clients and provide them what they need. Keep up the pace with innovation and make sure you talk about it. This seems rather simple, but is this most difficult combination you can imagine as it requires understanding, time and money to prepare the road to success.

At the end I would like to mention the most important player in all this: our people! We are living in a service industry that depends strongly and utterly on the skills and friendliness' of our staff. Over the past years it has become more and more difficult to find adequate staff that works for rather low salaries with a smile in the face. Motivation and treating these people professionally well seems difficult for many colleagues. Having them participate in success is not always financially possible. Nevertheless, do we all desperately depend on them, as they are the point of contact to our costumers at the end of the day!

\section{References}

1. Chaitip P. - Balogh, P. - Kovacs, S. - Chaiboonstri, Ch.: On tests for long-term Dependence: India's International Tourism Market. INTSM Conference, Debrecen, May 27-28., 2010

2. Hering K.: Turisztikai információs rendszerek fejlődése Magyarországon. INTSM Conference, Debrecen, May 27-28., 2010

3. Kelemen K. - Piskóti M. - Hoffmeister Tóth Á.: Környezettudatos fogyasztói magatartás a turizmusban. INTSM Conference, Debrecen, May 27-28., 2010

4. Kormosné Koch K.: Challenges for Hungary in Medical Tourism. INTSM conference, Debrecen, May 27-28., 2010

5. Simor, R.: Prospects for Growth in Medical Tourism. INTSM conference, Debrecen, May 27-28., 2010

6. Tikász I. E. - Kiss J. - Szabó B.: INTSM Conference, Debrecen, May 27-28., 2010

7. Tóth Z. - Török L.: Position of the Tourism and Gastronomy Sector in the Hungarian Economy. INTSM Conference, Debrecen, May 27-28., 2010

8. United Nations Word Tourism Organization (UNWTO): Why tourism? Tourism - an Economic and Social Phenomenon. http://www.unwto.org/aboutwto/why/en/why.php?op=1, April 21., 2010. 